\title{
Net energy levels of reduced crude protein, amino acid-supplemented diets for heavy pigs
}

\author{
Cintia Fracaroli*, Dani Perondi, Luan Sousa dos Santos, Welex Cândido da Silva, Alini Mari Veira, \\ Luciano Hauschild
}

São Paulo State University, School of Agricultural and Veterinarian Sciences, Animal Science Department, Jaboticabal CEP: 14883-108, Brazil

\section{A R T I C L E I N F O}

\section{Keywords:}

Carcass

Feeding behavior

Feed efficiency

Fat

\begin{abstract}
A B S T R A C T
This study aimed to investigate the effects of different net energy (NE) levels of diets with reduced crude protein (CP) that were supplemented with amino acids on feeding behavior, performance and carcass characteristics of heavy pigs (100-130 kg). Pigs were randomly allocated to experimental groups under a randomized complete block design with initial body weight as the blocking criterion. There were 5 treatments (NE levels: 2300, 2388, 2475, 2563 and $2650 \mathrm{Kcal} \mathrm{NE} / \mathrm{kg}$, as-fed basis) with 13 pigs per treatment, and the animal was the experimental unit. The diets were based on corn, soybean meal and wheat bran. CP levels were similar between diets and approximately $2 \%$ below the requirement (13.9\%). Pigs were weighed at the beginning and end of the experiment. Electronic feeder systems automatically recorded the visits to the feeders, the timing of meals, and the amount of feed consumed per meal. Based on these recorded data, daily feed intake was calculated and feeding behavior was evaluated. At the end of the experiment, the pigs were slaughtered for carcass evaluation. Net energy levels did not affect the average daily feed intake $(\mathrm{P}>0.05)$ but did influence the feeding behavior of the pigs. The pigs fed the 2388, 2475 and $2563 \mathrm{kcal} \mathrm{NE} / \mathrm{kg}$ diets had fewer $(\mathrm{P}<0.05)$ daily meals than those fed the 2300 and $2650 \mathrm{kcal} \mathrm{NE} / \mathrm{kg}$ diets. Thus, these animals occupied the feeders for less time daily $(\mathrm{P}<0.05)$ compared to those fed the 2300 and $2650 \mathrm{kcal} \mathrm{NE} / \mathrm{kg}$ diets. The average daily NE intake increased linearly $(\mathrm{P}<0.01)$ with increasing NE; however, average daily gain did not differ $(\mathrm{P}>0.05)$ between treatments. There was a quadratic relationship $(\mathrm{P}<0.01)$ between feed efficiency and increasing NE levels. The feed efficiency of pigs fed the $2563 \mathrm{kcal} \mathrm{NE} / \mathrm{kg}$ diet did not differ $(\mathrm{P}>0.05$ ) from that of pigs in the 2388 and $2475 \mathrm{kcal} \mathrm{NE} / \mathrm{kg}$ treatments, but was $9 \%$ higher $(\mathrm{P}<0.05)$ than in the 2300 and $2650 \mathrm{kcal}$ NE/kg treatments. Furthermore, loin depth and loin eye area did not change significantly $(P>0.05)$ when NE levels increased from 2300 to $2650 \mathrm{kcal} \mathrm{NE} / \mathrm{kg}$ in the diets. However, a linear effect $(\mathrm{P}<0.01)$ was observed for hot carcass yield and a trend toward a quadratic effect $(\mathrm{P}<0.10)$ for hot carcass weight, backfat thickness and lean percentage. Among the studied levels, 2388, 2475 and $2563 \mathrm{kcal} \mathrm{NE} / \mathrm{kg}$ produced the best results for reduced CP diets fed to heavy pigs because the pigs occupied the feeders for less time and showed higher feed efficiency.
\end{abstract}

\section{Introduction}

In Brazil, pigs are considered heavy when their body weight (BW) at slaughter is equal to or greater than $130 \mathrm{~kg}$ (MAPA, 2000). Recently, slaughtering heavy pigs has become a trend in Brazilian industrial swine farming. By adopting this practice, it is possible to optimize the high rates of weight gain achieved by selected animals and reduce operating costs both to the farm and the slaughterhouses. In addition, slaughterhouses can increase the added value of noble cuts such as ham, loin and shoulder since the weight of the pieces is also higher (Wood and Whittemore, 2006). Approximately $80 \%$ of Brazilian pork is exported as cuts (ABPA, 2016), and this further increases the interest in slaughtering heavy pigs.

However, higher BW implies high ingestion capacity and greater competition per feeder (Kyriazakis and Whittemore, 2006), when the adjusting the pen size, the number of feeders and drinkers is not considered. These aspects make the finishing phase quite costly to pig farmers especially due to the high volume of feed required. Furthermore, for pigs with BW higher than $90 \mathrm{~kg}$, much of the energy consumed is converted to fat and the consequence is reduced feed efficiency and decreased lean percentage on the carcass (Azain, 2001). Therefore, the search for nutritional strategies to minimize production costs and improve carcass quality for the industry has been a constant goal among nutritionists.

\footnotetext{
* Corresponding author.

E-mail address: cifracaroli@yahoo.com.br (C. Fracaroli).
} 
Energy and protein are important nutritional factors affecting carcass quality and represent more than $80 \%$ of the nutritional cost of practical diets for pigs (De Lange et al., 2001a). Thus, the diet nutrient composition should adequately meet the energy requirements of the animal and optimal amino acid balance. To satisfy an optimal balance of amino acids, the formulation of reduced CP diets supplemented with crystalline amino acids is a technique that has been widely discussed in various studies in the last few decades (Ball et al., 2013; Le Bellego et al., 2001; Tuitoek et al., 1997).

This nutritional strategy allows higher precision in meeting the amino acid requirements of the animals while avoiding excess protein intake and reducing nitrogen excretion in waste (Madrid et al., 2013). In this way, energy intake could be optimized since the reduction in energy costs to metabolize the excess protein could be directed toward improvement of animal performance. However, some studies have shown that the energy saved in the protein deamination and nitrogen excretion processes might be directed toward fat deposition on the carcass (Le Bellego et al., 2001; Madrid et al., 2013). This process can be even more intense in heavy pigs, which may require greater adjustments in diet energy levels.

Therefore, to meet the energy requirements of the animal it is very important to know the best energy system for use in the formulation of the diet. In contrast to digestible and metabolizable energy (ME) systems, the NE system allows more precise expression of the energy content of the diet by considering the differences in the metabolic utilization of ME among nutrients (Noblet and Van Milgen, 2004). In addition, $\mathrm{NE}$ is the only system in which energy requirements and diet energy values are expressed on the same basis, which should theoretically be independent of the feed characteristics (Noblet, 2007). In this sense, the NE system has attracted the interest of nutritionists mainly considering the reduction of diet costs.

However, there is a lack of information regarding the recommended level of NE for heavy pigs, especially when the option is to work with reduced $\mathrm{CP}$ diets. Studies considering this demand are fundamental for fostering interest in using this technology (reduced CP and NE) for pig production. Therefore, this study aimed to investigate the effects of different net energy (NE) levels of diets with reduced crude protein (CP) and supplemented with amino acids on feeding behavior, performance and carcass characteristics of heavy pigs (100-130 kg).

\section{Materials and methods}

All experimental procedures were reviewed and approved by the University Ethical Committee for the Care and Use of Experimental Animals (protocol No. 14226/15).

\subsection{Animals, experimental design and management}

Sixty-five castrated male pigs of the same high-performance genotype (Camborough $\times$ AGPIC337; Agroceres PIC Inc.) and with good health status were shipped in a single batch to the swine research facilities of the School of Agricultural and Veterinarian Sciences of São Paulo State University, Jaboticabal, Brazil. All pigs were housed in a single pen $\left(78 \mathrm{~m}^{2}\right.$; density $1.2 \mathrm{~m}^{2}$ /animal) with fully concrete flooring and equipped with automatic feeders and nipple drinkers. The internal temperature of the facility could not be measured. For this reason, the air temperature data were extracted from a collection of data belonging to the agrometeorology area of the Exact Sciences Department of the university campus.

The pigs were housed at $83 \pm 3.0 \mathrm{~kg}$ and were submitted to a 15 day adaptation period of feeding on a commercial diet based on corn and soybean meal formulated to meet the nutritional requirements (NRC, 2012) and provided through 5 automatic feeding stations (AIPF, Automatic and Intelligent Precision Feeder, University of Lleida, Lleida, Spain). Upon reaching the BW required to begin the experiment $(100 \pm 6.0 \mathrm{~kg})$, the animals were randomly distributed in blocks using
BW as the criterion across 5 treatments with 13 replicates; the animal was the experimental unit. The treatments consisted of diets with 5 different levels of NE $(2300,2388,2475,2563$ and $2650 \mathrm{Kcal} \mathrm{NE} / \mathrm{kg}$, as-fed basis) while $2475 \mathrm{kcal} \mathrm{NE} / \mathrm{kg}$ is the level proposed by the NRC (2012) for this phase.

The experiment lasted 32 days. Feed and water were provided ad libitum throughout the adaptation and experimental periods. Each AIPF consisted of a single-space feeder in which precision Archimedes screw conveyors delivered and simultaneously blended volumetric amounts of up to 4 feeds stored in independent containers located in the upper part of the AIPF (Pomar et al., 2011). In this experiment, there were only two, which were available in all feeders. The AIPF identifies each pig when their head is introduced into the feeder and then blends and delivers feed in response to each animal request according to the assigned experimental treatment (see Experimental diets section). In this way, any pig in the pen could access any feeder and receive the diet corresponding to the prescribed treatment for that animal.

One serving consisted of the amount of feed delivered on each effective serving request (serving size was $25 \mathrm{~g}$.). A time lag (18 s) was imposed to ensure that the pigs consumed each serving before requesting a new one. One meal included all the servings delivered during each feeder visit. Pigs tend to leave the feeder hopper empty or to only leave very small amounts of feed behind at each visit, and this behavior provides assurance that each pig received the assigned amount of blended feed. Feed density was measured weekly, and the feeders were calibrated accordingly to convert feed volume into feed weight. The use of exclusive identification codes allowed recording individual feed intake over the trial. All the feeders were designed to provide meals to all animals regardless of treatment. This feature allowed all animals to be housed in the same pen in a single group.

\subsection{Experimental diets}

The experimental diets were formulated with corn, soybean meal and wheat bran. The composition of these ingredients regarding crude protein (CP), ether extract (EE), starch (ST) and crude fiber (CF) was previously analyzed by Near-Infrared Reflectance Spectroscopy (NIRS). Subsequently, the NE level was determined using the equation proposed by Noblet et al. (1994): NE $(\mathrm{kcal} / \mathrm{kg})=0.73 \mathrm{ME}+13.1 \mathrm{EE}+3.7 \mathrm{ST}-$ 6.7 CP - 9.7 CF. The ME is expressed in $\mathrm{Kcal} / \mathrm{kg}$, and the EE, ST, CP and $\mathrm{CF}$ are expressed as percentages.

The chemical analysis results for corn, soybean meal, wheat bran and their respective NE calculations are shown in Table 1 . The nutritional composition of the raw materials used in the formulation, except for the values obtained by analysis (corn, soybean meal and wheat bran), was obtained from the Brazilian Poultry and Swine Tables (Rostagno et al., 2011).

Two diets were formulated to meet the nutritional requirements proposed by the NRC (2012): Diet A (high NE - $2650 \mathrm{kcal} \mathrm{NE/kg)} \mathrm{and}$ Diet B (low NE - $2300 \mathrm{kcal} \mathrm{NE} / \mathrm{kg}$ ), which served as the basis for the intermediate diets $(2388,2475$ and $2563 \mathrm{kcal} \mathrm{NE} / \mathrm{kg}$ ) by mixing the

Table 1

Chemical composition and net energy of the ingredients used in the experimental diets (as-fed basis).

\begin{tabular}{llll}
\hline Ingredients & Corn & Soybean meal & Wheat bran \\
\hline Dry matter, \% & 87.39 & 89.07 & 88.79 \\
Crude Protein, \% & 7.94 & 46.61 & 15.64 \\
Ether extract, \% & 4.10 & 2.50 & 3.80 \\
Starch, \% & 62.10 & 4.90 & 25.20 \\
Crude Fiber, \% & 1.70 & 5.30 & 7.70 \\
Metabolizable energy $^{\mathrm{a}}, \mathrm{kcal} / \mathrm{kg}$ & 3340 & 3154 & 2390 \\
Net energy $^{\mathrm{b}}, \mathrm{kcal} / \mathrm{kg}$ & 2652 & 1990 & 1708 \\
\hline
\end{tabular}

a Rostagno et al. (2011).

${ }^{\text {b }}$ From equation by Noblet et al. (1994). 
Table 2

Composition of experimental diets ${ }^{\mathrm{a}}$ (as-fed basis).

\begin{tabular}{|c|c|c|}
\hline Item & High net energy & Low net energy \\
\hline Ingredients, \% & Diet A & Diet B \\
\hline Corn & 76.67 & 71.47 \\
\hline Soybean meal & 6.96 & 7.11 \\
\hline Wheat bran & 9.42 & 13.53 \\
\hline Soybean oil & 4.00 & 0.00 \\
\hline Dicalcium phosphate & 0.72 & 0.67 \\
\hline Limestone & 0.70 & 0.72 \\
\hline Salt & 0.21 & 0.23 \\
\hline Kaolin & 0.00 & 5.00 \\
\hline Dextrin & 0.50 & 0.50 \\
\hline L- Lysine $\mathrm{HCl}$ & 0.44 & 0.43 \\
\hline DL- Methionine & 0.03 & 0.02 \\
\hline L- Threonine & 0.10 & 0.10 \\
\hline L- Tryptophan & 0.04 & 0.02 \\
\hline Choline chloride $60 \%$ & 0.06 & 0.06 \\
\hline Vitamin and mineral premix ${ }^{\mathrm{b}}$ & 0.15 & 0.15 \\
\hline \multicolumn{3}{|l|}{ Calculated composition } \\
\hline Dry matter, $\%$ & 87.84 & 88.02 \\
\hline Metabolizable energy kcal/kg & 3349 & 2959 \\
\hline Net energy, $\mathrm{kcal} / \mathrm{kg}$ & 2650 & 2300 \\
\hline Crude protein, $\%$ & 11.41 & 11.70 \\
\hline Ether extract, \% & 7.67 & 3.62 \\
\hline Ash, $\%$ & 3.10 & 8.11 \\
\hline Crude fiber, \% & 2.34 & 2.60 \\
\hline SID $^{\mathrm{c}}$ Lysine, \% & 0.70 & 0.70 \\
\hline SID Methionine, \% & 0.20 & 0.19 \\
\hline SID Methionine + cysteine, $\%$ & 0.39 & 0.38 \\
\hline SID Threonine, $\%$ & 0.42 & 0.42 \\
\hline SID Tryptophan, \% & 0.13 & 0.12 \\
\hline Calcium, \% & 0.47 & 0.47 \\
\hline Total phosphorus, \% & 0.45 & 0.46 \\
\hline Available phosphorus, $\%$ & 0.23 & 0.23 \\
\hline \multicolumn{3}{|l|}{ Analyzed composition } \\
\hline Dry matter, \% & 90.96 & 90.27 \\
\hline Crude protein, \% & 11.73 & 11.80 \\
\hline Ether extract, \% & 7.96 & 4.03 \\
\hline Ash, \% & 2.87 & 7.66 \\
\hline Crude fiber, \% & 2.24 & 2.49 \\
\hline Calcium, \% & 0.53 & 0.50 \\
\hline Total phosphorus, \% & 0.48 & 0.47 \\
\hline
\end{tabular}

a The three intermediate diets were prepared by mixing $\mathrm{A}$ and $\mathrm{B}$ diets in suitable proportions to achieve the net energy level for each treatment $(2388 \mathrm{kcal} / \mathrm{kg}=25 \mathrm{~A}: 75 \mathrm{~B}$, $2475 \mathrm{kcal} / \mathrm{kg}=50 \mathrm{~A}: 50 \mathrm{~B}$ and $2563 \mathrm{kcal} / \mathrm{kg}=75 \mathrm{~A}: 25 \mathrm{~B})$.

b Mineral vitamin supplement (per kg of diet): Vit. A (5.250 UI); Vit. D3 (750 UI); Vit. E (11 UI); Vit. K3 (1.5 mg); Vit. B1 (1 mg); Vit. B2 (2,4 mg); Vit. B6 (1 mg); Niacin (30 mg); Pantothenic acid (8.1 mg); Folic acid (0.53 mg); Biotin (0.05 mg); Vit. B12 (16.5 mcg); Copper (13.5 mg); Iodine (0.19 mg); Manganese (37.5 mg); Selenium (0.15 mg); Zinc (72 mg); Iron (72 mg); Cobalt (0.19 mg).

${ }^{\mathrm{c}}$ Standardized ileal digestible.

appropriate proportions. The A and B diets were blended at each service to each pig according to the NE level treatment assigned to that animal. The CP level was similar in all diets and was approximately $2 \%$ lower than that suggested by Rostagno et al. (2011) for this phase (13.9\%), and the diet included crystalline amino acid supplementation. The contents of standardized ileal digestible lysine and other amino acids were also similar among the diets. The feed was steam-pelleted at $3 \mathrm{~mm}$.

Diets A and B were analyzed for moisture (method 930.15), CP (method 992.15), ash (method 942.05), EE (method 920.39) and CF (method 978.10) according to the procedures of AOAC International (2005). Calcium and total phosphorus were determined by the ICP-OES method 2011.14 (AOAC, 1990). All the analyses were performed in duplicate. The ingredient composition and nutrient content (calculated and analyzed) of the diets are shown in Table 2.

\subsection{Performance and feeding behavior}

The animals were weighed at the beginning (day 0) and end (day
32) of the experiment, and the feed intake of each animal was recorded daily by the AIPF. At the end of the experimental period, the recorded data were used to calculate the average daily gain (ADG), average daily feed intake (ADFI), average daily NE intake, feed efficiency (ADG: ADFI) and NE efficiency (ADG: NE intake, kg/Mcal).

On day 0 of the experiment, ultrasound images were collected for the initial evaluation of backfat thickness and loin depth using ALOKA ${ }^{\circledast}$ equipment $(500 \mathrm{v}$ series with a linear probe of $3.5 \mathrm{MHz}, 13.5 \mathrm{~cm})$. The measurements were taken at the boundary of the thoracic and lumbar vertebrae ( $\mathrm{P} 2$, behind the last rib), at six centimeters from the midline (ABCS, 1973). The measurements were performed by the Image-Pro Plus $^{\circledast}$ software (version 4.5).

For the evaluation of feeding behavior, the records of feeder visits by the AIPF were used. Considering that the feed was available $24 \mathrm{~h}$ a day and there was a ratio of 13 animals per AIPF (following the density indicated by the manufacturer), each pig had approximately $111 \mathrm{~min}$ available per day to feed. Feeder visits by the same pig with intervals that were less than $1 \mathrm{~min}$ apart were combined as a single meal in a revised spreadsheet. Feeding information collected on days in which animals were handled (weighed or scanned) was removed from the data set. After this preliminary review procedure, the database was used to calculate the number of meals per day, feeder occupancy (min/day), feeding time per meal (min), intervals between meals (min), feed intake per meal $(\mathrm{g})$, and feed intake rate (feed intake divided by feeding time per meal expressed in $\mathrm{g} / \mathrm{min}$ ) of each animal.

\subsection{Carcass characteristics}

At the end of the experiment, animals were slaughtered at $130 \pm 8.6 \mathrm{~kg}$ after an $18 \mathrm{~h}$ fasting period. The pigs were desensitized by electronarcosis and submitted to the standard slaughtering procedure. After evisceration, the carcasses were sectioned longitudinally (cut along the spinal column) and weighed to obtain hot carcass weight (HCW). The HCW included the weight of the head. The half-carcasses were placed in a cold room at $2^{\circ} \mathrm{C}$ for $24 \mathrm{~h}$ (ABCS, 1973). The hot carcass yield (HCY) was given by the ratio percentage of HCW: BW before slaughtering (last pre-shipment weighing).

The left half-carcass of each animal was sectioned at P2 perpendicular to the dorso-lumbar line to measure backfat thickness, loin depth and loin eye area. The backfat thickness and loin depth were measured from point $\mathrm{P} 2$ using a pachymeter ( $0.5 \mathrm{~mm}$ accuracy). Backfat thickness was measured at the $90^{\circ}$ angle formed between one of the opening ends of the caliper with the skin surface and extending the other end to the fat-muscle interface. Then, in the same direction, loin depth was measured in the space between the backfat thickness boundary and the opposite extremity of the Longissimus dorsi muscle. Subsequently, the P2 region was drawn on vegetal paper according to the methodology proposed by ABCS (1973). From this drawing, the loin eye area was determined using Image-Pro Plus ${ }^{\circledast}$ software. The lean percentage was obtained by the equation proposed by Guidoni (2000): $\%$ Lean $=65.92$ - (0.685*backfat thickness) + (0.094*loin depth) - (0.026*HCW), where backfat thickness and loin depth are expressed in $\mathrm{mm}$ and obtained in the cooled carcass, and HCW is expressed in $\mathrm{kg}$.

\subsection{Statistical analysis}

Data were analyzed by ANOVA using the MIXED procedure of the statistical program SAS ${ }^{\circledast}$ version 9.3 (SAS Inst. Inc., Cary, NC, USA). The pig was the experimental unit for all analyses. Block was the random effect and NE level was the fixed effect. The LSMEANS procedure was used to calculate mean values. Differences among means were considered significant if $\mathrm{P}<0.05$ and as a trend if $\mathrm{P}<0.10$. When there was a significant effect of treatment, the adjusted means were compared using the Tukey-Kramer test. Orthogonal contrasts were performed to detect linear and quadratic effects on the performance and carcass characteristics variables. 
Table 3

Feeding behavior of heavy pigs fed diets with different levels of net energy (NE) ${ }^{1}$.

\begin{tabular}{|c|c|c|c|c|c|c|c|}
\hline \multirow[t]{2}{*}{ Item } & \multicolumn{5}{|c|}{$\mathrm{NE}(\mathrm{kcal} / \mathrm{kg})$} & \multirow[t]{2}{*}{$\mathrm{SEM}^{2}$} & \multirow[t]{2}{*}{ P-value } \\
\hline & 2300 & 2388 & 2475 & 2563 & 2650 & & \\
\hline $\begin{array}{l}\text { Number of meals per } \\
\text { day }\end{array}$ & $6.7^{\mathrm{a}}$ & $5.2^{\mathrm{bc}}$ & $5.1^{\mathrm{c}}$ & $5.6^{\mathrm{b}}$ & $6.6^{\mathrm{a}}$ & 0.169 & $<0.01$ \\
\hline $\begin{array}{l}\text { Feeder occupancy, min/ } \\
\text { day }\end{array}$ & $67.3^{\mathrm{a}}$ & $61.0^{\mathrm{b}}$ & $62.0^{\mathrm{b}}$ & $62.2^{\mathrm{b}}$ & $68.4^{\mathrm{a}}$ & 2.832 & $<0.01$ \\
\hline $\begin{array}{l}\text { Feeding time per meal, } \\
\text { min }\end{array}$ & $10.4^{\mathrm{b}}$ & $12.0^{\mathrm{a}}$ & $12.7^{\mathrm{a}}$ & $11.4^{\mathrm{b}}$ & $10.9^{\mathrm{b}}$ & 0.722 & $<0.01$ \\
\hline Feed intake rate, $\mathrm{g} / \mathrm{min}$ & $41.9^{\mathrm{b}}$ & $46.1^{\mathrm{a}}$ & $46.4^{\mathrm{a}}$ & $45.9^{\mathrm{a}}$ & $42.8^{\mathrm{b}}$ & 0.765 & $<0.01$ \\
\hline Feed intake per meal, $g$ & $433^{c}$ & $551^{\mathrm{a}}$ & $585^{\mathrm{a}}$ & $523^{\mathrm{b}}$ & $469^{c}$ & 29.554 & $<0.01$ \\
\hline $\begin{array}{l}\text { Interval between meals, } \\
\text { min }\end{array}$ & $158^{\mathrm{b}}$ & $195^{\mathrm{a}}$ & $207^{\mathrm{a}}$ & $203^{\mathrm{a}}$ & $163^{\mathrm{b}}$ & 6.278 & $<0.01$ \\
\hline
\end{tabular}

Within a row, means with a common superscript letter are not significantly different $(\mathrm{P}<0.05)$.

${ }^{1}$ Adjusted means.

${ }^{2}$ Standard error of the mean.

\section{Results}

\subsection{Feeding behavior}

The results of feeding behavior variables are presented in Table 3. The animals fed the 2300 and $2650 \mathrm{kcal} \mathrm{NE} / \mathrm{kg}$ diets took a higher number of meals per day $(\mathrm{P}<0.05)$ than those fed the intermediate diets. Among the intermediate diets, a significant difference $(\mathrm{P}<0.05)$ was observed between the responses of the animals fed $2563 \mathrm{kcal} \mathrm{NE} /$ $\mathrm{kg}$ and $2475 \mathrm{kcal} \mathrm{NE} / \mathrm{kg}$. However, the animals in the groups fed the 2388 and $2475 \mathrm{kcal} \mathrm{NE} / \mathrm{kg}$ diets had similar responses (P >0.05).

Of the 111 min daily that each pig had available to feed, only $60 \%$ of this time on average was used for this purpose (i.e., daily feeder occupancy). The time when one or more AIPFs were unoccupied can correspond to the periods in which the animals are lying down, drinking water or walking through the pen. The time of daily feeder occupancy was similar $(P>0.05)$ for the 2300 and $2650 \mathrm{kcal} \mathrm{NE} / \mathrm{kg}$ diets. The animals fed intermediate diets had similar $(\mathrm{P}>0.05)$ times of daily feeder occupancy, but spent approximately 9\% less time $(\mathrm{P}<0.05)$ than the other two NE levels $(2300$ and $2650 \mathrm{kcal} \mathrm{NE} / \mathrm{kg}$ ). Regarding the feeding time per meal, the responses for the lowest and highest NE levels did not differ $(\mathrm{P}>0.05)$ and were similar $(\mathrm{P}>0.05)$ to those observed for the $2563 \mathrm{kcal} \mathrm{NE} / \mathrm{kg}$ group. However, the animals fed the 2388 and $2475 \mathrm{kcal} \mathrm{NE} / \mathrm{kg}$ diets showed higher feeding time per meal $(\mathrm{P}<0.05)$ compared to the other treatments.

The pigs fed the 2300 and $2650 \mathrm{kcal} \mathrm{NE} / \mathrm{kg}$ diets had the same $(P>0.05)$ feed intake rates, which were lower $(P<0.05)$ than the intermediate diets. The feed intake per meal was lower $(\mathrm{P}<0.05)$ for the 2300 and $2650 \mathrm{kcal} \mathrm{NE} / \mathrm{kg}$ diets compared to the other treatments. The group fed the $2563 \mathrm{kcal} \mathrm{NE} / \mathrm{kg}$ diet had higher $(\mathrm{P}<0.05)$ feed intake per meal than those fed the 2388 and $2475 \mathrm{kcal} \mathrm{NE} / \mathrm{kg}$ diets, which did not differ $(\mathrm{P}>0.05)$.

Likewise, the interval between meals was also the same $(\mathrm{P}>0.05)$ for animals fed the 2300 and $2650 \mathrm{kcal} \mathrm{NE} / \mathrm{kg}$ diets. The pigs fed the 2388, 2475 and $2563 \mathrm{kcal} \mathrm{NE} / \mathrm{kg}$ diets had similar intervals between meals, which were on average $20 \%$ higher $(\mathrm{P}<0.05)$ than the 2300 and $2650 \mathrm{kcal} \mathrm{NE} / \mathrm{kg}$ diets.

\subsection{Performance}

The performance results are shown in Table 4. No differences ( $P>0.05$ ) were observed for initial BW and measurements of backfat thickness and loin depth obtained on day 0 of the experiment. This result demonstrates the effectiveness of the distribution of the animals in blocks by adopting the initial BW as the criterion.

Over the entire experimental period, the animals consumed $2.8 \mathrm{~kg}$ / animal/day on average. The NE levels did not influence $(\mathrm{P}>0.05)$ ADFI. Consequently, NE intake increased linearly $(\mathrm{P}<0.01)$ with increasing NE levels in the diets. Animals fed the 2388-2650 kcal NE/kg diets showed similar NE intakes $(\mathrm{P}>0.05)$. The lowest NE intake was observed in animals fed the $2300 \mathrm{kcal} \mathrm{NE} / \mathrm{kg}$ diet. The final BW showed an increasing trend $(P<0.10)$ with increasing NE levels of the diets. However, ADG was not significantly ( $P>0.05$ ) affected by the different NE levels studied.

The feed efficiency was influenced by NE levels (quadratic; $\mathrm{P}<0.01$ ). Animals fed the 2388, 2475 and $2563 \mathrm{kcal} \mathrm{NE} / \mathrm{kg}$ diets showed similar feed efficiency $(\mathrm{P}>0.05)$. However, the feed efficiency of pigs fed the $2563 \mathrm{kcal} \mathrm{NE} / \mathrm{kg}$ diet was approximately 9\% higher $(P<0.05)$ than in the groups fed the 2300 and $2650 \mathrm{kcal} \mathrm{NE} / \mathrm{kg}$ diets. $\mathrm{NE}$ efficiency showed a quadratic response $(\mathrm{P}<0.01)$ to increased $\mathrm{NE}$ levels of the diets. The animals fed the $2650 \mathrm{kcal} \mathrm{NE} / \mathrm{kg}$ diets had the lowest NE efficiency values, which were $11 \%$ lower $(\mathrm{P}<0.05)$ than in the other treatments.

\subsection{Carcass characteristics}

The results obtained for the carcass characteristics are shown in Table 5. The HCW showed a trend toward a quadratic response $(\mathrm{P}<0.10)$ to increased NE levels of the diets; however, the HCY increased linearly $(\mathrm{P}<0.01)$. The animals fed the lowest $\mathrm{NE}$ level $(2300 \mathrm{kcal} \mathrm{NE} / \mathrm{kg}$ ) had $1.5 \%$ lower HCY $(\mathrm{P}<0.05)$ compared to the highest level $(2650 \mathrm{kcal} \mathrm{NE} / \mathrm{kg})$. However, the HCY was not significantly $(\mathrm{P}>0.05)$ different when the NE level increased from 2388 to $2650 \mathrm{kcal} \mathrm{NE} / \mathrm{kg}$.

The NE levels did not influence $(P>0.05)$ loin depth and loin eye area. However, backfat thickness showed a trend toward a quadratic response $(P<0.10)$ to increased NE levels of the diets. Nevertheless, lean percentage was not affected by NE levels and only showed a trend toward a quadratic response $(\mathrm{P}<0.10)$.

\section{Discussion}

The external average air temperature during the experiment $\left(21.1 \pm 0.94{ }^{\circ} \mathrm{C}\right)$ was within the thermoneutral zone proposed by Le Bellego et al. (2002), who considered $22^{\circ} \mathrm{C}$ as comfortable for pigs in the finishing phase. Although the experiment was conducted in the winter, the experimental unit is in a predominantly hot and dry region, and for this reason, daily environmental management was intensified. Additionally, a density of $1.2 \mathrm{~m}^{2} /$ animal was adopted to facilitate movement and allow the animals to designate a waste-only area. Carr (2006) suggested a minimum space of $1 \mathrm{~m}^{2} /$ animal for pigs over $110 \mathrm{~kg}$.

\subsection{Feeding behavior}

The feeding behavior of pigs is influenced by several factors such as housing density, BW, genotype, sex, environment, sanitary conditions, feed type (mash or pelleted), feeding system and diet characteristics (Ellis and Augspurger, 2001; Maselyne et al., 2015). The concentration of energy in the diet strongly influences the modulation of daily feed intake of pigs (Patience, 2012). In the present study, NE levels did not affect the ADFI of the animals, but influenced feeding behavior. The feeding behavior responses of the pigs in this experiment were similar to those reported by Boumans et al. (2015) for the same BW range.

Feed intake is controlled by the central nervous system through physical and chemical stimuli released by the gastrointestinal tract, which signals animal satiety (Forbes, 1995; Ryan et al., 2012). These signals can be expressed by distension of the stomach (De Castro et al., 1981) and by the entry of nutrients into the intestine (mainly lipids and fatty acids), which stimulate the release of cholecystokinin, a peptide signaling satiety (Ryan et al., 2012). The $2300 \mathrm{kcal} \mathrm{NE} / \mathrm{kg}$ diet contained a considerable amount of wheat bran (13.53\%), which may have 
Table 4

Performance of heavy pigs fed diets with different levels of net energy (NE) ${ }^{1}$.

\begin{tabular}{|c|c|c|c|c|c|c|c|c|}
\hline \multirow[t]{2}{*}{ Item } & \multicolumn{5}{|c|}{$\mathrm{NE}(\mathrm{kcal} / \mathrm{kg})$} & \multirow[t]{2}{*}{$\mathrm{SEM}^{2}$} & \multicolumn{2}{|l|}{ P-value ${ }^{3}$} \\
\hline & 2300 & 2388 & 2475 & 2563 & 2650 & & $\mathrm{~L}$ & $\mathrm{Q}$ \\
\hline \multicolumn{9}{|l|}{ Initial conditions } \\
\hline BW, kg & 100.86 & 100.91 & 100.41 & 100.38 & 99.86 & 3.960 & 0.234 & 0.787 \\
\hline Backfat thickness, mm & 15.48 & 15.12 & 15.35 & 14.94 & 16.14 & 0.717 & 0.546 & 0.261 \\
\hline Loin depth, mm & 64.00 & 65.53 & 63.95 & 62.76 & 64.11 & 1.725 & 0.547 & 0.993 \\
\hline \multicolumn{9}{|l|}{$0-32$ days } \\
\hline$\overline{\text { Final BW, } \mathrm{kg}}$ & 131.02 & 133.14 & 133.10 & 134.58 & 131.61 & 5.454 & 0.551 & 0.097 \\
\hline ADFI, $\mathrm{kg} / \mathrm{d}$ & 2.80 & 2.77 & 2.86 & 2.78 & 2.90 & 0.133 & 0.350 & 0.645 \\
\hline $\mathrm{ADG}, \mathrm{kg} / \mathrm{d}$ & 0.975 & 1.007 & 1.020 & 1.045 & 0.994 & 0.049 & 0.460 & 0.198 \\
\hline Feed efficiency, kg/kg & $0.342^{\mathrm{b}}$ & $0.364^{\mathrm{ab}}$ & $0.358^{\mathrm{ab}}$ & $0.375^{\mathrm{a}}$ & $0.343^{\mathrm{b}}$ & 0.006 & 0.534 & $<0.01$ \\
\hline NE intake, $\mathrm{kcal} / \mathrm{d}$ & $6440^{\mathrm{b}}$ & $6620^{\mathrm{ab}}$ & $7070^{\mathrm{ab}}$ & $7130^{\mathrm{ab}}$ & $7690^{\mathrm{a}}$ & 0.335 & $<0.01$ & 0.598 \\
\hline NE efficiency, $\mathrm{kg} / \mathrm{Mcal}$ & $0.147^{\mathrm{a}}$ & $0.152^{\mathrm{a}}$ & $0.145^{\mathrm{a}}$ & $0.146^{\mathrm{a}}$ & $0.130^{\mathrm{b}}$ & 0.003 & $<0.01$ & $<0.01$ \\
\hline
\end{tabular}

Within a row, means with a common superscript letter are not significantly different $(\mathrm{P}<0.05)$;.

${ }^{1}$ Adjusted means.

${ }^{2}$ Standard error of the mean.

${ }^{3}$ P-value for linear $(\mathrm{L})$ and quadratic $(\mathrm{Q})$ contrasts $(\mathrm{P}<0.05)$.

Table 5

Carcass characteristics of heavy pigs fed diets with different levels of net energy (NE) ${ }^{1}$.

\begin{tabular}{|c|c|c|c|c|c|c|c|c|}
\hline \multirow[t]{2}{*}{ Item } & \multicolumn{5}{|c|}{$\mathrm{NE}(\mathrm{kcal} / \mathrm{kg})$} & \multirow[t]{2}{*}{$\mathrm{SEM}^{2}$} & \multicolumn{2}{|l|}{ P-value ${ }^{3}$} \\
\hline & 2300 & 2388 & 2475 & 2563 & 2650 & & $\mathrm{~L}$ & $\mathrm{Q}$ \\
\hline Hot carcass weight, $\mathrm{kg}$ & 102.95 & 105.45 & 105.83 & 106.57 & 105.33 & 4.398 & 0.104 & 0.099 \\
\hline Hot carcass yield, $\%$ & $79.77^{\mathrm{b}}$ & $80.71^{\mathrm{ab}}$ & $80.77^{\mathrm{ab}}$ & $80.47^{\mathrm{ab}}$ & $81.01^{\mathrm{a}}$ & 0.263 & $<0.01$ & 0.247 \\
\hline Backfat thickness, mm & 22.46 & 22.23 & 27.42 & 24.38 & 23.62 & 2.259 & 0.310 & 0.082 \\
\hline Loin depth, mm & 69.68 & 69.30 & 66.16 & 69.42 & 70.13 & 1.477 & 0.815 & 0.112 \\
\hline Lean percentage $\mathrm{e}^{4}, \%$ & 55.86 & 55.97 & 51.88 & 54.42 & 55.05 & 1.683 & 0.377 & 0.075 \\
\hline Loin eye area, $\mathrm{cm}^{2}$ & 63.57 & 67.71 & 60.98 & 64.13 & 63.44 & 2.224 & 0.500 & 0.975 \\
\hline
\end{tabular}

Within a row, means with a common superscript letter are not significantly different $(P<0.05)$.

${ }^{1}$ Adjusted means.

${ }^{2}$ Standard error of the mean.

${ }^{3} \mathrm{P}$-value for linear $(\mathrm{L})$ and quadratic $(\mathrm{Q})$ contrasts $(\mathrm{P}<0.05)$.

${ }^{4}$ Estimated by equation from Guidoni (2000).

contributed to initiating the satiety sensation of the animals by distending the stomach, thereby resulting in lower feed intake per meal. Pigs regulate feed consumption to maintain an appropriate balance between energy supply and requirements (Martin et al., 1989). In this sense, the animals fed the lowest NE level diet ( $2300 \mathrm{kcal} \mathrm{NE} / \mathrm{kg}$ ) took more daily meals to meet the energy requirements due to lower consumption per meal. Similar results were found in rats fed diets with low caloric density (Kanarel, 1976; Johnson et al., 1986).

The motivation for animal feed intake is also influenced by the palatability of the feed (Boumans et al., 2015) and is more intense when fat levels in the diet are higher (Azain, 2001). The diet with $2650 \mathrm{kcal} \mathrm{NE} / \mathrm{kg}$ had higher levels of soybean oil (4\%), which may have motivated the pigs to visit the feeder more often during the day. However, the high caloric content may have limited feed intake per meal due to the sensation of satiety, which was probably triggered by increased plasma concentrations of cholecystokinin in response to the high dietary lipid content (Ryan et al., 2012).

The duration and amount of feed eaten per meal are determined by the animal satiation status (Forbes, 1995). Under ad libitum feeding conditions, the animals stop feeding after satiation while the next meal begins when the sensation of satiety decreases to below a critical point (Maselyne et al., 2015). The critical point depends on the amount of feed consumed in the previous meal and determines whether the intervals between meals are longer or shorter. Therefore, the animals fed the 2300 and $2650 \mathrm{kcal} \mathrm{NE} / \mathrm{kg}$ diets had a shorter interval between meals because feed intake per meal was lower compared to the other treatments. The low feed intake per meal of these two groups shortened the feeding time per meal, resulting in lower feed intake rates. However, the higher number of meals per day increased the time of daily feeder occupancy in the groups fed the 2300 and $2650 \mathrm{kcal} \mathrm{NE} / \mathrm{kg}$ diets compared to the others.

The responses to diets in the groups with three intermediate levels of NE were similar for daily feeder occupancy, feed intake rate and the interval between meals. This result suggests a range of energy levels in which pig feeding behavior varies little. Additionally, the time of daily feeder occupancy of animals fed the intermediate diets was approximately $9 \%$ lower compared to the 2300 and $2650 \mathrm{kcal} \mathrm{NE} / \mathrm{kg}$ diets. In practical conditions, where facilities were not properly planned to handle high-slaughter pigs, competition for feeder space dispute tends to be larger, which may affect nutrient intake. Considering that daily food intake depends on meeting the animal's energy needs, one way of minimizing the impact of food disputes may be to manipulate the energy level of the diets to provide an adequate intake of nutrients in which the animal does not need to stay a long time feeding. Furthermore, the energy saved when less physical activity is required during feed consumption can optimize animal performance.

\subsection{Performance}

Pigs tend to ingest feed until the daily energy requirement is met (Kil et al., 2013). Thus, diet energy density strongly affects the ADFI (Noblet and Van Milgen, 2004). In the present study, however, increasing NE levels did not influence the ADFI. As a result, the NE intake increased linearly. Similarly, other studies reported no differences in the ADFI with increasing NE levels in finishing pig diets (Chen et al., 2011; Kerr et al., 2003; Zhang et al., 2011). The results of this study corroborated those of De la Llata et al. (2001) and Kerr et al. (2003), which suggest that in later growth stages, the pigs are little affected by 
changes in dietary energy. However, the same is not observed for animals below $40 \mathrm{~kg}$, where ADFI and consequently performance are dependent on diet energy level (Campbell et al., 1985). Thus, the range of NE levels of the studied diets seemed sufficient to meet the energy demands of the pigs.

The ADG results agree with those obtained by Cámara et al. (2016), De la Llata et al. (2001) and Suarez-Belloch et al. (2013). These authors also reported no differences for ADG with the increasing NE of finishing pig diets. In the early stages of growth, it was observed that protein deposition increased linearly with increasing energy intake (Bikker et al., 1996). In these stages, the energy required for growth may exceed the feed intake capacity. However, in the finishing phase, the ingestion capacity exceeds the energy requirement for animal growth (Van Milgen and Noblet, 2003). Assuming that the NE intake of the animals in the present study was sufficient to meet the requirements, the increasing NE levels did not affect the ADG and consequently the final BW. However, even if there is no significant difference, the numerical behavior of the ADG data may explain the trend toward a quadratic response to increasing NE levels observed for final BW. The consequence of this response is reflected in the feed efficiency.

Diet energy level strongly affects pig feed efficiency (Patience, 2012). Studies have shown that feed efficiency improved with increasing energy in diets (Apple et al., 2004; Beaulieu et al., 2009; Hinson et al., 2011). Energy requirements for growing animals can be partitioned into priority requirements for maintenance, thermoregulation, and energy deposition in body tissues (NRC, 1998). Thus, under reduced NE intake, the NE has lower availability for body weight gain (Patience, 2012). This fact may explain the low feed efficiency observed in the animals fed the $2300 \mathrm{kcal} \mathrm{NE} / \mathrm{kg}$ diet. However, it does not apply to the result found in the treatment with $2650 \mathrm{kcal} \mathrm{NE} / \mathrm{kg}$, which presented similar feed efficiency with $2300 \mathrm{kcal} \mathrm{NE} / \mathrm{kg}$ and lower NE efficiency compared to the other groups. This result seems contradictory because, theoretically, there should be more available NE for gain in these animals. The energy requirement for normal physical activity (without challenges) has been considered part of maintenance in energy partitioning models (Van Milgen et al., 2001). Thus, it is possible that the NE balance available for weight gain in the animals fed the $2650 \mathrm{kcal} \mathrm{NE} / \mathrm{kg}$ diet was reduced as a function of the additional energy expenditure caused by changed eating behavior (i.e., higher number of visits to the feeder) and contributed to reducing the NE efficiency of these animals.

The animals fed the $2563 \mathrm{kcal}$ NE/ kg diet had higher feed efficiency compared to those fed the 2300 and $2650 \mathrm{kcal} \mathrm{NE} / \mathrm{kg}$ diets. The feed efficiency of animals fed the 2388 and $2475 \mathrm{kcal} \mathrm{NE} / \mathrm{kg}$ diets was similar to those fed the $2563 \mathrm{kcal} \mathrm{NE} / \mathrm{kg}$ diet. This suggests an NE interval $(2388-2563 \mathrm{kcal} \mathrm{NE} / \mathrm{kg}$ ) in which animal performance can be optimized. The NRC (2012) recommends $2475 \mathrm{kcal} \mathrm{NE} / \mathrm{kg}$ for this phase. However, the existence of this interval increases the possibility of choosing an ideal NE level for heavy pigs, which can be better determined through an economic evaluation.

\subsection{Carcass characteristics}

The NE level of the diets did not influence the HCW of the animals according to the study of Cámara et al. (2014), Cámara et al. (2016), Liu et al. (2007), Suarez-Belloch et al. (2013) and Zhang et al. (2011). However, in the present study, the HCY increased linearly with increasing NE levels of the diets. Normally, low energy diets have higher amounts of fiber than high energy diets (Noblet and Le Goff, 2001). The fiber intake might increase the weight of the gastrointestinal tract and consequently produce lower carcass yield (Cámara et al., 2016). The CF content varied by approximately $10 \%$ between the high and low NE diets. Considering the daily feed intake, this difference may explain the $1.5 \%$ lower HCY of the animals fed the $2300 \mathrm{kcal} \mathrm{NE} / \mathrm{kg}$ diet compared to those fed higher NE levels. This difference becomes more import considering the cost of energy in the diet and the form of payment of the producer, which in most cases considers the HCY (Guidoni, 2000). In pigs, protein deposition increases linearly with energy intake to reach the maximal protein deposition (PDmax) (De Lange et al., 2001b). Pigs heavier than $100 \mathrm{~kg} \mathrm{BW}$ need to consume a feed level of 2-2.5 times the ME for maintenance to reach the PDmax (Van Milgen and Noblet, 2003). In the present study, NE intake appears to have been sufficient for animals to reach PDmax, even for pigs fed the diet with the lowest energy level (2.7 times the ME for maintenance). Once the PDmax has been reached, increased NE intake does not result in increased protein deposition (Van Milgen and Noblet, 2003), which may explain the fact that loin depth and loin eye were not different between treatments. Similar responses were found by Chen et al. (2011), Quiniou and Noblet (2012) and Zhang et al. (2011).

NE intake above the level required to reach the PDmax is incorporated as fat (De Lange et al., 2001b). In the present study, assuming that NE intake was sufficient to achieve the PDmax, a linear effect on backfat thickness (increasing) and lean percentage (decreasing) would be expected with increasing dietary NE. However, backfat thickness and lean percentage showed a trend toward a quadratic response to increasing dietary NE. The reasons for this discrepancy are not very clear. However, the probable cause for low feed efficiency for the 2300 and $2650 \mathrm{kcal} \mathrm{NE} / \mathrm{kg}$ diets compared to the others, possibly also applies to backfat thickness and lean percentage. The additional NE expenditure of these animals with physical activity may have resulted in a lower NE balance available for fat deposition; consequently, backfat thickness was reduced and lean percentage was increased.

\section{Conclusion}

This study indicated that feeding heavy pigs with net energy levels of reduced crude protein, amino acid-supplemented diets from 2388 to $2563 \mathrm{kcal} \mathrm{NE} / \mathrm{kg}$ produced the best response. Below or above these NE levels in the diets, pigs spent more time at the feeders and presented lower feed efficiency.

\section{Acknowledgements}

The authors thank the National Council for Scientific and Technological Development (CNPq - Brazil) for the scholarships granted to the first author (Process No. 132399/2015-6) and the São Paulo Research Foundation (FAPESP - Brazil) for the financial support for this study (Process No. 2012/03781-0).

\section{References}

ABCS, 1973. Associação Brasileira dos Criadores de Suínos. Método Brasileiro de Classificação de Carcaças, pub. tec. n.2, Estrela, Rio Grande do Sul.

ABPA, 2016. Associação brasileira de Proteína animal. Relatório Anu. 〈http://abpa-br. com.br/files/publicacoes/c59411a243d6dab1da8e605be58348ac.pdf $>$ (Accessed 2 September 2016).

AOAC, 1990. Association of Oficial Analytical Chemists. Official methods of analysis, 15th ed. AOAC International, Arlington.

AOAC, 2005. Association of Oficial Analytical Chemists. Official methods of analysis, 18th ed. AOAC International, Maryland.

Apple, J.A., Maxwell, C.V., Brown, D.C., Friesen, K.G., Musser, R.E., Johnson, Z.B., Armstrong, T.A., 2004. Effects of dietary lysine and energy density on performance and carcass characteristics of finishing pigs fed ractopamine. J. Anim. Sci. 82, 3277-3287.

Azain, M.J., 2001. Fat in swine nutrition. In: Lewis, A.J., Southern, L.L. (Eds.), Swine Nutrition, 2th ed. CRC Press, New York, pp. 95-106.

Ball, M.E.E., Magowan, E., McCracken, K.J., Beattie, V.E., Bradford, R., Gordon, F.J., Robinson, M.J., Smyth, S., Henry, W., 2013. The effect of level of crude protein and available lysine on finishing pig performance, nitrogen balance and nutrient digestibility. Asian Australas. J. Anim. Sci. 26, 564.

Beaulieu, A.D., Williams, N.H., Patience, J.F., 2009. Response to dietary digestible energy concentration in growing pigs fed cereal grain-based diets. J. Anim. Sci. 87, 965-976.

Bikker, P., Verstegen, M.W., Campbell, R.G., 1996. Performance and body composition of finishing gilts ( 45 to $85 \mathrm{~kg}$ ) as affected by energy intake and nutrition in earlier life: II. protein and lipid accretion in body components. J. Anim. Sci. 74, 817-826.

Boumans, I.J.M.M., Bokkers, E.A.M., Hofstede, G.J., de Boer, I.J.M., 2015. Understanding 
feeding patterns in growing pigs by modeling growth and motivation. Appl. Anim. Behav. Sci. 171, 69-80.

Cámara, L., Berrocoso, J.D., Sánchez, J.L., López-Bote, C.J., Mateos, G.G., 2014. Influence of net energy content of the diets on productive performance and carcass merit of gilts, boars and immunocastrated males slaughtered at $120 \mathrm{~kg}$ BW. Meat Sci. 98, 773-780.

Cámara, L., Berrocoso, J.D., Coma, J., López-Bote, C.J., Mateos, G.G., 2016. Growth performance and carcass quality of crossbreds pigs from two Pietrain sire lines fed isoproteic diets varying in energy concentration. Meat Sci. 114, 69-74.

Campbell, R.G., Taverner, M.R., Curic, D.M., 1985. The influence of feeding level on the protein requirement of pigs between 20 and $45 \mathrm{~kg}$ live weight. Anim. Prod. 40, 489-496.

Carr, J., 2006. The maintenance of health. In: Kyriazakis, I., Whittemore, C.T. (Eds.), Whittemore's Science and Practice of Pig Production, 3th ed. Blackwell Publishing Ltd, Oxford, pp. 263-315.

Chen, H., Yi, X., Zhang, G., Lu, N., Chu, L., Thacker, P.A., Qiao, S., 2011. Studies on reducing nitrogen excretion: 1 . Net energy requirements of finishing pigs maximizing performance and carcass quality fed low crude protein diets supplemented with crystalline amino acids. J. Anim. Sci. Biotechnol. 2, 84-93.

De Castro, J.M., 1981. The stomach energy content governs meal patterning in the rat. Physiol. Behav. 26, 795-798.

De la Llata, M., Dritz, S.S., Tokach, M.D., Goodband, R.D., Nelssen, J.L., Loughin, T.M., 2001. Effects of dietary fat on growth performance and carcass characteristics of growing-finishing pigs reared in a commercial environment. J. Anim. Sci. 79, 2643-2650.

De Lange, C., Marty, B.J., Birkett, S., Morel, P., Szkotnicki, B., 2001a. Application of pig growth models in commercial pork production. Can. J. Anim. Sci. 81, 1-8.

De Lange, C.F.M., Birkett, S., Morel, P., 2001b. Protein, fat, and bone tissue growth in swine. In: Lewis, A.J., Southern, L.L. (Eds.), Swine Nutrition, 2th ed. CRC Press, New York, pp. 65-81.

Ellis, M., Augspurger, N., 2001. Feed intake in growing-finishing pigs. In: Lewis, A.J., Southern, L.L. (Eds.), Swine Nutrition, 2th ed. CRC Press, New York, pp. 447-468.

Forbes, J.M., 1995. Feeding behavior. In: Forbes, J.M. (Ed.), Voluntary Food Intake and Diet Selection in Farm Animals. CAB International, Wallingford, pp. 11-37.

Guidoni, A.L., 2000. Melhoria de processos para a tipificação e valorização de carcaças suínas no Brasil. In: Anais da conferência internacional virtual sobre qualidade de carne suína. Embrapa Suínos e Aves, Concórdia, Brasil, pp. 221-234.

Hinson, R.B., Wiegand, B.R., Ritter, M.J., Allee, G.L., Carr, S.N., 2011. Impact of dietary energy level and ractopamine on growth performance, carcass characteristics, and meat quality of finishing pigs. J. Anim. Sci. 89, 3572-3579.

Johnson, D.F., Ackroff, K., Peters, J., Collier, G.H., 1986. Changes in rat's meal patterns as a function of the caloric density of the diet. Physiol. Behav. 36, 929-936.

Kanarek, R.B., 1976. Energetics of meal patterns in rats. Physiol. Behav. 17, 395-399.

Kerr, B.J., Southern, L.L., Bidner, T.D., Friesen, K.G., Easter, R.A., 2003. Influence of dietary protein level, amino acid supplementation, and dietary energy levels on growing-finishing pig performance and carcass composition. J. Anim. Sci. 81, 3075-3087.

Kil, D.Y., Kim, B.G., Stein, H.H., 2013. Feed energy evaluation for growing pigs. Asian Australas. J. Anim. Sci. 26, 1205-1217.

Kyriazakis, I., Whittemore, C.T., 2006. Appetite and voluntary feed intake. In: Kyriazakis, I., Whittemore, C.T. (Eds.), Whittemore's Science and Practice of Pig Production, 3th ed. Blackwell Publishing Ltd, Oxford, pp. 417-436.

Le Bellego, L., Van Milgen, J., Dubois, S., Noblet, J., 2001. Energy utilization of lowprotein diets in growing pigs. J. Anim. Sci. 79, 1259-1271.

Le Bellego, L., Van Milgen, J., Noblet, J., 2002. Effect of high temperature and lowprotein diets on the performance of growing-finishing pigs. J. Anim. Sci. 80, 691-701.

Liu, Z.H., Yang, F.Y., Kong, L.J., Lai, C.H., Piao, X.S., Gu, Y.H., Ou, X.Q., 2007. Effects of dietary energy density on growth, carcass quality and mRNA expression of fatty acid synthase and hormone-sensitive lipase in finishing pigs. Asian Australas. J. Anim. Sci. 20, 1587-1593.

Madrid, J., Martínez, S., López, C., Orengo, J., López, M.J., Hernández, F., 2013. Effects of low protein diets on growth performance, carcass traits and ammonia emission of barrows and gilts. Anim. Prod. Sci. 53, 146-153.

MAPA, 2000. Ministério da Agricultura, Pecuária e Abastecimento. Instrução Normativa 22. 〈http://sistemasweb.agricultura.gov.br/sislegis/action/detalhaAto.do?Method= consultarLegislacaoFederal〉 (Accessed 15 November 2016).

Martin, R.J., Beverly, J.L., Truett, G.E., 1989. Energy balance regulation. In: Campion, R.D., Hausman, G.J., Martin, R.J. (Eds.), Animal Growth Regulation. Plenum Press, New York, pp. 211-236.

Maselyne, J., Saeys, W., Van Nuffel, A., 2015. Review: quantifying animal feeding behaviour with a focus on pigs. Physiol. Behav. 138, 37-51.

Noblet, J., Fortune, H., Shi, X.S., Dubois, S., 1994. Prediction of net energy value of feeds for growing pigs. J. Anim. Sci. 72, 344-354.

Noblet, J., Le Goff, G., 2001. Effect of dietary fiber on the energy value of feeds for pigs. Anim. Feed Sci. Tech. 90, 35-52.

Noblet, J., Van Milgen, J., 2004. Energy value of pig feeds: Effect of pig body weight and energy evaluation system. J. Anim. Sci. 82, E229-E238.

Noblet, J., 2007. Net energy evaluation of feeds and determination of net energy requirements for pigs. Rev. Bras. Zootec. 36, 277-284.

NRC, 1998. Nutrient Requirements of Swine, 10th rev. ed. National Academy Press, Washington, DC.

NRC, 2012. Nutrient Requirements of Swine, 11th rev. ed. National Academy Press, Washington, DC.

Patience, J.F., 2012. The influence of dietary energy on feed efficiency in grow-finish swine. In: Patience, J.F. (Ed.), Feed Efficiency in Swine, (ed.). Wageningen Academic Publishers, Wageningen, pp. 101-129.

Pomar, J., López, V., Pomar, C., 2011. Agent-based simulation framework for virtual prototyping of advanced livestock precision feeding systems. Comput. Electron. Agr. 78, 88-97.

Quiniou, N., Noblet, J., 2012. Effect of the dietary net energy concentration on feed intake and performance of growing-finishing pigs housed individually. J. Anim. Sci. 90, $4362-4372$.

Rostagno, H.S., Albino, L.F.T., Donzele, J.L., Gomes, P.C., Oliveira, R.F., Lopes, D.C., Ferreira, A.S., Barreto, S.L.T., Euclides, R.F., 2011. Tabelas Brasileiras para Aves Suínos: Composição de Alimentos e Exigências Nutricionais. Editora UFV, Viçosa.

Ryan, K.K., Woods, S.C., Seeley, R.J., 2012. Central nervous system mechanisms linking the consumption of palatable high-fat diets to the defense of greater adiposity. Cell Metab. 15, 137-149.

Suarez-Belloch, J., Sanz, M.A., Joy, M., Latorre, M.A., 2013. Impact of increasing dietary energy level during the finishing period on growth performance, pork quality and fatty acid profile in heavy pigs. Meat Sci. 93, 796-801.

Tuitoek, K., Young, L.G., De Lange, C.F.M., Kerr, B.J., 1997. The effect of reducing excess dietary amino acids on growing-finishing pig performance: an elevation of the ideal protein concept. J. Anim. Sci. 75, 1575-1583.

Van Milgen, J., Noblet, J., 2003. Partitioning of energy intake to heat, protein, and fat in growing pigs. J. Anim. Sci. 81, E86-E93.

Van Milgen, J., Noblet, J., Dubois, S., 2001. Energetic efficiency of starch, protein and lipid utilization in growing pigs. J. Nutr. 131, 1309-1318.

Wood, J., Whittemore, C.T., 2006. Pig Meat and carcass quality. In: Kyriazakis, I., Whittemore, C.T. (Eds.), Whittemore's Science and Practice of Pig Production, 3th ed. Blackwell Publishing Ltd, Oxford, pp. 4-61.

Zhang, G.-j., Yi, X.-w., Chu, L.-c., Ning, L.U., Htoo, J., Qiao, S.-y., 2011. Effects of dietary net energy density and standardized ileal digestible lysine: net energy ratio on the performance and carcass characteristic of growing-finishing pigs fed low crude protein supplemented with crystalline amino acids diets. Agr. Sci. China 10, 602-610. 